\title{
THE EFFECTS OF TRANSFORMATIONAL AND LAISSEZ-FAIRE LEADERSHIPS ON ORGANIZATIONAL COMMITMENTS OF HEALTH CARE WORKERS IN TEMPORARY STAFF
}

\author{
*Zehra Binnur AVUNDUK (Orcid ID: 0000-0001-6627-6454) \\ *Guner COL (Orcid ID: 0000-0002-9222-4399) \\ *Ali KUZU (Orcid ID: 0000-0002-0027-2829) \\ *Istanbul University-Cerrahpasa, Turkey
}

\begin{abstract}
In today's challenging competitive environment, companies aiming to precede have to find, employ and retain qualified employees, who are the main actors in this competition. This can only be possible by making a sense of commitment in the workforce and empowering this sense among the staff. Undoubtedly, the most important task in establishing and strengthening the commitment falls to the internal leaders of the organization; because the leadership styles and behaviors exhibited by the intra-organizational leaders are crucial in the formation of the employees' commitment to the organization that they work for. Therefore, in this study it is aimed to investigate the effects of transformational leadership and laissez-faire leadership on organizational commitment types. The sample of the study includes employees working in temporary staff at an important public hospital in Istanbul. As the data collection tool, survey forms prepared on a 5point Likert scale were used. In order to measure the transformational leadership and laissez-faire leadership types, the Multifactor Leadership Questionnaire (MLQ) developed by Avolio, Bass and Jung (1999) was used whereas to measure the organizational commitment types, the scale developed by Allen and Meyer (1990) was used. The organizational commitment scale consists of three dimensions: continuance commitment, affective commitment and normative commitment. Structural equation modelling was used as the research method. The data was evaluated by statistical tests using IBM SPSS and AMOS programs, and reliable and valid results were achieved. As a result of the analyses performed, it was found that transformational leadership has a highly meaningful and positive effect on all three dimensions of organizational commitment. On the other hand, while laissez-faire leadership has a meaningful and positive effect on continuance commitment and normative commitment, it has no significant impact on affective commitment.
\end{abstract}

Keywords: Transformational Leadership, Laissez-faire Leadership, Organizational Commitment, Health Workers

\section{INTRODUCTION}

Recent developments in information and technology have accelerated globalization, increased competition between businesses and led to significant changes in business life. No matter how fast this technological change which causes the re-determination of the competition rules, human resource remains the most important factor in production. Because of this, every business that tries to keep up with this rapid change is trying to keep the qualified employees within the organization by increasing their organizational commitment, because those who have a high level of commitment to the organization they work for are making an effort more than expected to achieve organizational goals.

Any business that wants to keep the employees (who make extra efforts to achieve organizational goals, who are happy in the organization and want to remain in the organization) must identify and implement the factors that are effective in maintaining organizational commitment and increasing its level. One of these factors is the leader behavior that directly or indirectly shapes the organizational structure and working conditions. It is clear that the behaviors of the leaders within the organization affect the attitudes and behaviors of the employees against the organization in which they work. Therefore, it is extremely 
important for the leader to be able to convince and direct members of the organization to behave in line with his/her requests; Because managers are primarily responsible for ensuring productivity and profitability in businesses. As a requirement of this responsibility, the main task of leaders in organizations is to use all the resources of the organization, especially the workforce, effectively for organizational purposes. In this context, leaders must motivate employees to achieve organizational goals and persuade them to use their physical / intellectual capacities to the end and to make more effort than expected. From here, as they are the leaders who set organizational goals and guide employees, it is possible to say that leadership style is an important variable in the establishment of organizational commitment.

In this context, the possible effects of transformational leadership and laissez-faire leadership on the organizational commitment types are discussed in this study. When the literature is examined, it is seen that there are lots of works on leadership and organizational commitment relationship. However, since almost all these studies were done on permanent staff, any study related with the temporary staff was not found. For this reason, a model was designed to investigate the impacts of transformational leadership and laissezfaire leadership on the organizational commitment types of health care workers in temporary staff, and the variables within the scope of the research were associated with each other one by one.

\section{LEADERSHIP}

Leadership can be defined as a process of influencing and directing others' activities under certain circumstances to achieve specific personal purposes or objectives of a group (Deitzer, Shilliff \& Jucius, 1979). For this reason, leadership is a process of what the leader does. Leader is the person who leads others to act for a specific purpose and has an influence on their thoughts and behaviors. People follow the leader to achieve their personal and group objectives and act in accordance with the leader's orders and instructions (Koçel, 2005). In other words, leadership is to inspire subordinates by extraordinary efforts (Bass, 1985). A formal organizational structure is not required for the formation of leadership. In order for leadership to be formed within the organization, the leader does not need to be equipped with official powers, and also leadership is not a phenomenon valid only for the upper levels of the organization. For example, either a senior manager or a foreman can be a leader. Therefore, leadership can be seen at all levels within the organization (Koçel, 2005).

Leaders can take their power from different sources, but the most important issue here is to encourage the employees to work willingly by persuading them to achieve the objectives of the organization, not by using the power of the position. Even if they are not aware of it, another important issue is that leaders should understand how their behaviors affect employees (Bohn \& Grafton, 2002). For this reason, leaders must consciously carry out every action that they will perform, because they are role models for their subordinates.

One of the key points for groups within the organization is the degree of strength and control. Sometimes groups may be harmed by low levels of participation, distress or apathy. Some groups or individuals succeed in a more structured and authoritarian management style, while others succeed in an opposite style of management. For example, while employees in the manufacturing department succeed in an environment dominated by a more structured and authoritarian management style, groups working in the research department can succeed when managed more independently (Harvey \& Brown, 1988).

Although there are different types of leaderships in the literature, transformational leadership and laissezfaire leadership were discussed as independent variables in this study.

\section{Transformational Leadership}

Transformational leadership is the process of positively and significantly changing the needs, beliefs and values of individuals, groups, teams and organizations (Warrick, 2011). A transformational leader is the one who delivers organizations to superior performance by realizing change and renewal. This success can only be possible through the leader having a vision and making the followers internalize that vision. Vision fuels the excitement of employees by making organizational life meaningful (Koçel, 2005).

According to Bernard Bass (1985), who led the research and development of the concept of transformational leadership, transformational leader has certain behavioral features. These are: to be unifying and honest, to set clear goals, to have high expectations, to promote and encourage people, to excite them, to support them and to achieve high purposes by enabling people to look beyond their personal 
interests. Bass (1990: 22) examined the transformational leadership in various dimensions. These are: "charisma, inspiration, intellectual stimulation and individual importance". Kitchin (2010) stated that the transformational leader should have vision and charisma. The transformational leader is the one who is inspired by confidence, communicates with a positive vision, emphasizes the strengths of his followers and looks at the future from a positive perspective (Peterson, Walumbwa, Byron \& Myrowitz, 2009).

By strongly influencing the members of the organization, the transformational leader enables organizational goals to take over the personal expectations of employees. In other words, organizational purposes make more sense for employees. In such a case, the priority for employees is the realization of the purposes of the business. For this reason, they put their personal expectations on the back burner and concentrate on their duties to fulfill their responsibilities willingly. Naturally, together with the purposes of the organization, the personal purposes of the employees are also realized, but the priorities are displaced here. In other words, there has been a transformation in the mindset and value system of the employees, related to their jobs. The architect of this transformation is the transformational leader and the success of this transformation depends on the characteristics of transformational leaders (Ülgen \& Mirze, 2007).

Characteristics of transformational leaders are; persuading employees to do business for organizational purposes or the purposes of the group, encouraging members of the organization to participate in decisions, managing them through personal characteristics - not using the position, and making members of the organization feel good about themselves (Brewis \& Linstead, 2004). Wang and Huang (2009), the proponents of this idea, who studied on textile companies in Taiwan found that "emotional intelligence" was a positive premise of transformational leadership, which leads to the formation of high levels of group commitment.

The transformational leader is essentially seen as the person who; increases the interests of his subordinates, motivates them to ensure their personal developments and supplies their individual needs. These behaviors reflect the "relationship-oriented" behavior type, more than the "change-oriented" behavior. Motivating behaviors such as role modeling and vision giving in transformational leadership can be used to build commitment to traditional or revolutionary goals and strategies (Yukl, 1999).

\section{Laissez-Faire Leadership}

The philosophy of this leadership is "let them do it!" and refers to the leader who completely frees his employees in their decisions. According to Bass (1997), the opposite of transactional leadership requires liberating behavior, and such leaders often have qualifications that are mostly passive, avoiding decisionmaking, afraid of responsibilities and not present when needed. The laissez-faire leadership frees the group to make their own decisions and complete their work (Robbins \& Coulter, 2012). In fact, this type of management is the absence of leadership or avoiding leadership. Not acting, avoiding decision-making and not being present when needed are the characteristics of this type of leadership (Judge \& Piccolo, 2004). The laissez-faire leadership, which does not take any action even when problems become chronic, is strongly associated with the dissatisfaction, conflict and inefficiency of subordinates. However, at the beginning, with the transfer of authority, it has been associated with empowerment-like elements such as allowing employees to take initiative and allow them to solve problems in the way they know best. Empowerment is the leader's "giving autonomy" to subordinates; But it requires that the subordinates, who are related to the authority transferred, should focus on that job with all their interests and thoughts (Bass, 1999).

Although this type of leadership has similarities with "management by passive exception", the two concepts are different. Because, while trying to protect the current situation in "management by passive exception", the status quo is ignored in laissez-faire leadership which avoids decision-making and other administrative responsibilities (Bass, 1998).

\section{ORGANIZATIONAL COMMITMENT}

Organizational commitment is defined as attitudes and feelings of dedicating yourself to the organization such as selflessness in favor of the organization, serving to organizational purposes loyally or even faithfully while contributing to individual desires, goals and values, and forming a suitable environment for them to happen (Eren, 2012). When the literature is examined, it is seen that the first comprehensive studies on organizational commitment began in 1960s and continue to increase today (e.g. Becker, 1960; Bull 
Schaefer, et. al., 2013, Cook \& Wall, 1980; Curtis \& Taylor, 2018; Çöl, 2004; Dubin \& Champoux, 1975; Durna \& Eren, 2005; Erdem, 2007; Grusky, 1966; Hartmann \& Bambacas, 2000; Hrebiniak \& Alutto, 1972; Kanter, 1968; Kidron, 1978; Meyer \& Allen, 1991; Mowday, et. al., 1979; Thornton, 1970; Porter, et. al., 1974; Porter, et. al., 1976; Posey, Roberts, \& Lowry, 2015; Rossel, 1971; Sadeghi \& Pihie, 2012; Yousef, 2017; Yüceler, 2009).

Commitment in general refers to our loyalty to a person, a thought, an institution, or an entity that we consider greater than ourselves and an obligation that we must fulfill (Çöl, 2004). With organizational commitment, the individual contributes to organizational purposes and values, serves for the benefit of the organization and defends the organization everywhere. Organizational commitment requires behaviors of adopting the institution internally and supporting it; accepting and respecting its strategies, policies, procedures, purposes, rules, norms and culture (Eren, 2012). Meyer and Allen conceptualized organizational commitment with three separate components. These are: continuance commitment - stating a need, affective commitment - expressing a desire, and normative commitment - expressing an obligation to continue working in the organization (Meyer \& Allen, 1991).

Continuance commitment is related to, the cost that the employee will face in financial and non-financial matters if he leaves work (Becker, 1960) and the absence of other alternatives (Ritzer \& Trice, 1969; Hrebiniak \& Alutto, 1972). In the past, organizations have developed regulations to punish the employees who leave work untimely, such as promotion depending on the tenure, accrued pensions and sick leave. Other possible costs of leaving work are; loss of labor in cases where skills and systems are not transferable, damage to family life and missing the future opportunities. The presence of other business alternatives and their appropriate perception have a negative impact on organizational commitment of employees and may cause job dissatisfaction (Hartmann \& Bambacas, 2000).

Although affective commitment is related to personal features, organizational structure and work experience (such as wages, supervision, role clarity, and talent diversity), it also expresses the sense of belonging to the organization and feelings of commitment with love (Hartmann \& Bambacas, 2000). Affective commitment occurs when feelings of adopting mission, vision, strategy, policy, purpose, goal, rule, principle, norms and values of the organization; identification with them; supporting organizational activities wholeheartedly; and establishing personal identification with the organization are generated. This is because factors such as faith, respect and love to the organization and its managers, and sharing common values contribute significantly to the formation of affective commitment. Employees see and adopt institutions as an indispensable entity for the society, the environment and themselves; the institution needs to be served and raised, and managers are seen as charismatic authorities (Eren, 2012). Affective commitment also offers a psychological orientation (Meyer \& Allen, 1991). Affective commitment refers to; the identification of employees with the institution they work for, being happy to be a member of the organization, and emotional tendency showing that they are strongly connected to the organization. People with high affective commitment stay in the organization "because they want to" and they are willing to make the maximum efforts for the interests of the organization. Therefore, it is considered as the most desired type of commitment to occur in organizations and is intended to be instilled in the employees (Uyguç \& Çımrın, 2004).

Normative commitment reflects the sense of obligation of employees who feel that they need to stay in the organization (Meyer \& Allen, 1991). According to another definition, employees behaving just because of believing that what they're doing is right and moral, acting in a way to meet organizational goals and interests, and all the internalized normative pressures constitutes commitment (Wiener, 1982). In a study by Wiener and Vardi in 1980, the participants of the research stated that they believe in the following view about normative commitment: "An employee; should be faithfully committed to the institution, dedicate itself to the organization and not criticize it" (Wiener \& Vardi, 1980: 86). Under the scope of normative commitment, employees think that an imbalance has occurred in the employee-organization relationship as a result of the organization's investments in them and as a result of this, the employee feels that he has to dedicate himself to the organization until he pays back this debt (Scholl, 1981). 


\section{THE RELATIONSHIP BETWEEN TRANSFORMATIONAL AND LAISSEZ-FAIRE LEADERSHIPS AND ORGANIZATIONAL COMMITMENT}

Ensuring a positive shaping of attitudes of employees towards the leader and the organization is one of the main objectives of leadership. The leader's open and clear sharing of the organization's mission and vision with its subordinates enables the adoption of these core values more easily by the employees and their identification with the organization. Employees who feel that their individual needs, feelings and thoughts are taken into account by the leader may exhibit behaviors such as; easily adoption of decisions made within the organization, identification with the organization and continuation of the organization membership with an emotional connection it has developed against the organization (Batmunkh, 2011). Organizational commitment can be seen as a driving force in improving the success of the institution by ensuring the construction of trust, loyalty and positive feelings of the employee against the organization. At this point, it can be argued that the attitude, behavior and paths shown by the leader have an impact on the commitment of the employees to the organization.

When the studies in the literature are examined, it is seen that the relations between; organizational commitment and transformational leadership (Avolio et. al, 2004), normative commitment and transformational leadership (Yücel, McMillan \& Richard, 2014), affective commitment and transformational leadership (Kim, 2014), and organizational commitment and leadership types (Acar, 2012; Aydın, Sarıer \& Uysal, 2013; Çakınberk, Demirel, 2010; Eryeşil, İraz, 2017; Salepçioğlu, Yeğin, 2018) have been discussed. In their research on 140 bank employees in Konya city center, Eryeşil and İraz (2017) found a positive and meaningful relationship between the perception of transformational and managerial leaderships and organizational commitment while detecting a negative, very weak and statistically insignificant relationship between the perception of laissez-faire leadership and organizational commitment and its sub-sizes.

Transformational leaders give vision to their followers, encourage them to trust themselves, motivate and support them by coaching. Employees who feel this, perform a superior performance by keeping the interests of the organization above their own interests. In this way, both an appropriate working environment is established and commitment of motivated employees with high success drives are increased; and they are moving away from thoughts such as absenteeism or leaving the work (Çakınberk \& Demirel, 2010). For this reason, it can be argued that transformational leadership increases the organizational commitment of employees.

In an organization with laissez-faire leadership, because the followers determine their goals and make plans and decisions themselves, their individual ingenuity emerges. This style of leadership is suitable for groups of responsible subordinates with professional expertise. However, in organizations where laissez-faire leadership exists, gathering employees around common goals and directing them is lacking. In this case, conflicts can arise within the group. In addition, while employees are trying to achieve their own individual goals that they set themselves, it is possible to experience uncertainties and failures in reaching the organizational goals, since they may have opposing goals (Aysel, 2006). While it is frequently stated in the literature that transformational leadership style is positively related with organizational commitment, the lack of clear views on laissez-faire leadership indicates that further work is needed in this area. In this study, the following hypotheses have been developed to seek answers to the questions of which type of leadership affects which sub-dimension of organizational commitment:

- $\mathrm{H}_{1}$ : Transformational leadership has a meaningful and positive effect on affective commitment.

- $\mathrm{H}_{2}$ : Transformational leadership has a meaningful and positive effect on continuance commitment.

- $\mathrm{H}_{3}$ : Transformational leadership has a meaningful and positive effect on normative commitment.

- $\mathrm{H}_{4}$ : Laissez-faire leadership has a meaningful and positive effect on affective commitment.

- $\mathrm{H}_{5}$ : Laissez-faire leadership has a meaningful and positive effect on continuance commitment.

- $\mathrm{H}_{6}$ : Laissez-faire leadership has a meaningful and positive effect on normative commitment. 


\section{RESEARCH METHODOLOGY}

In this research, the effects of transformational and laissez-faire leadership perceptions of employees working in temporary staff at an important public hospital in Istanbul, on the types of organizational commitment are discussed. The random sampling method was chosen in the research and survey method was used as the data collection tool. 300 questionnaires were hand-distributed to randomly selected employees and 170 answers were received. The fact that the participation rate in the survey is not high indicates that those working as temporary staff avoid to answer the questionnaire about the organization they work for; because most employees refused to fill out the questionnaire even though their credentials were not requested, and submitted it blank.

The survey form consists of three parts: The first part contains demographic questions and the other two parts contain items to measure the leadership types and organizational commitment. In order to measure transformational and laissez-faire leadership types, the Multifactor Leadership Questionnaire (MLQ) developed by Avolio, Bass and Jung (1999) was used, and to measure organizational commitment types, the scale developed by Allen and Meyer (1990) was used. For the Turkish expressions of the leadership scale, Sayın's (2008) study was used. The organizational commitment scale consists of three dimensions: continuance commitment, affective commitment and normative commitment. Data were collected using a 5-point Likert scale to determine the degree of participation in the statements in the questionnaire. Accordingly, the statements were listed as "1-strongly disagree", "2-disagree", "3-neutral", "4-agree", "5strongly agree".

When the demographic characteristics of the participants examined, it's seen that; $46 \%$ of them are between ages $30-39,57 \%$ are women, $64 \%$ are married, $58 \%$ are high school graduates, $42 \%$ have an undergraduate (or above) degree, $50 \%$ of their working time in the current institution is between $0-5$ years and $96 \%$ of them work with minimum wage.

Structural equation modeling (SEM) technique was used as the methodology of the research. In this context, reliability and validity analysis, confirmatory factor analysis (CFA) and path analysis were applied. IBM SPSS 21.0 and IBM SPSS AMOS 22.0 package programs were used for statistical analysis. In order to test the research model, covariance-based structural equation modeling, which is a multiple regression method, was used.

"The most widely used forecasting method in structural equation modeling is the maximum likelihood (ML) function" (Bollen, 1989: 107). Simulation studies have shown that under ideal conditions, ML estimation provides valid and stable results even with sample sizes as small as 50. On the other hand, as the sample size increases $(>400)$, the method becomes more sensitive and goodness of fit values become weaker. In order to provide a sound basis for estimation, sample sizes from 100 to 400 are recommended (Hair Jr. et. al., 2010). The fact that 170 healthcare workers participated in this study shows that the ideal sample size has been achieved for the use of ML estimator.

\section{Statistical Analysis and Findings}

In the first phase of the research, the reliability analysis of the scale was carried out. Cronbach's Alpha reliability coefficient (a) is the most widely used measure that assesses the reliability of the entire scale (Hair Jr. et. al. 2014a). Cronbach (1951) stated that the $\alpha$ level should be 0.70 or higher in order to ensure the internal consistency. Hair Jr. et.al. (2010) stated that for $\alpha$, which takes values between 0 and 1 , the values 0.70 or above are satisfactory, and the range of $0.60-0.70$ is also acceptable. Cronbach's alpha value was found to be 0.940 for the entire scale. This value, which is very close to 1 -the perfect reliability level, indicates that the reliability level of the data obtained with the scale used in our research is very high. In addition to the high overall reliability level of the scale, when the reliability levels of the scales are examined separately, it is seen that Cronbach's alpha coefficients are between 0.735 and 0.952 . These values indicate that the scales used in the research are highly reliable.

In the second phase of the research, confirmatory factor analysis (CFA) was applied. "CFA tests the measurement model of variables" (Acar et. al., 2017: 1298). At this stage of the study, the measurement model, that is, the consistency of the structure for path analysis, was tested. In order to test the structure validity; reliability coefficients (Cronbach's alpha and composite reliability), and divergent and convergent validity results were examined. Composite reliability takes values between 0 and 1 , with higher values 
indicating higher levels of reliability and it is generally interpreted in the same way as Cronbach's alpha value (Hair Jr.,2014b). While the fact that for these two values, greater than 0.70 is a measure of acceptability, it is also stated in some sources that values over 0.60 are also acceptable (Bagozzi \& Yi, 1988; Tseng, Dörnyei \& Schmitt, 2006: 92).

Campbell and Fiske (1959) stated that divergent and convergent validity are necessary to ensure structure validity. The sub-dimensions that measure a structure must have a certain amount of correlations between themselves in order to be parts of this structure (convergent validity); on the other hand, each dimension must be different from each other to be able to exist alone (divergent validity) (Özoğlu \& Bülbül, 2013). In order to check that convergent validity is maintained, the average variance extracted (AVE) value is considered and this value is recommended to be higher than 0.50 (Fornell \& Larcker, 1981). In order to ensure the divergent validity, which means that a scale is sufficiently different from other related scales within the structure, the AVE value must be higher than the maximum shared variance (MSV) between structures (Hair Jr. et. al. 2014a; Gaskin \& Lim, 2016).

The reliability and validity analysis results of the structures used in the research are given in Table 1 and Table 2. When these values are examined, it is seen that all dimensions are highly reliable, and all the above-mentioned criteria related to structure validity are met.

Table 1: Reliability and Validity Analysis Results of the Leadership Structure

\begin{tabular}{lllllll}
\hline & C. $\alpha$ & CR & AVE & MSV & TL & LFL \\
\hline Transformational Leadership (TL) & 0.952 & 0.950 & 0.516 & 0.008 & 0.718 & \\
Laissez-faire Leadership (LFL) & 0.735 & 0.751 & 0.511 & 0.008 & -0.087 & 0.715 \\
\hline
\end{tabular}

Table 2: Reliability and Validity Analysis Results of the Organizational Commitment Structure

\begin{tabular}{llllllll}
\hline & C. $\boldsymbol{\alpha}$ & CR & AVE & MSV & AC & CC & NC \\
\hline Affective Commitment (AC) & 0.881 & 0.880 & 0.554 & 0.385 & $\mathbf{0 . 7 4 4}$ & & \\
Continuance & 0.828 & 0.833 & 0.500 & 0.339 & $0.526^{* * *}$ & $\mathbf{0 . 7 0 7}$ & \\
Normative & 0.854 & 0.857 & 0.549 & 0.385 & $0.621^{* * *}$ & $0.582^{* * *}$ & $\mathbf{0 . 7 4 1}$ \\
\hline$* * * \mathrm{p}<0.001$ & & & & & & &
\end{tabular}

The items that decrease the model fit were removed from the analysis in the CFA. In addition to reliability and validity tests within the CFA, final factors have been obtained, taking into account the modification indexes, factor loadings and goodness of fit (GoF) values. CFA is used as a confirmatory test of the theoretical measurement modal and gives information about the validity of the model (Hair et. al., 2010). "The model fit determines the degree of compliance of the structural equation model with the sample data" (Schermelleh et. al, 2003: 24). Several GoF indices are used to test the harmony of the data used in the research with the model measured. In this study, GoF indices; $\chi 2 / d f$, CFI, TLI, IFI and RMSEA, which are frequently used in the SEM studies in literature were used. The GoF values which shows that the CFA results are successful are presented in Table 3.

Table 3: Confirmatory Factor Analysis - Goodness of Fit Indices

\begin{tabular}{llllll} 
& $\chi^{2} / \mathbf{d f}$ & CFI & TLI & IFI & RMSEA \\
\hline Leadership & 2.224 & 0.905 & 0.845 & 0.906 & 0.08 \\
Organizational Commitment & 1.956 & 0.929 & 0.914 & 0.931 & 0.07 \\
\hline
\end{tabular}

In order to ensure GoF, in the literature, while values less than 5 for the $\chi 2 / \mathrm{df}$ criteria are said to be acceptable (Marsh \& Hocevar, 1985), values under 3 are good and values less than 2 are better in terms of model compliance (Kline, 2011). It is considered good if the CFI value is 0.90 or higher, and in addition, it is frequently reported in researches that for the TLI and CFI indices (which typically take values between 0 and 1), goodness of fit increases as the value gets closer to 1 (Hair Jr. et. al., 2014a). Like CFI and TLI, 
for the IFI criteria, values 0.90 or above show good compliance, but values closer to 1 represent better goodness of fit. Unlike others, for RMSEA criteria, values approaching 0 show better goodness of fit and values less than 0.10 are considered acceptable (Meyers et. al, 2006). Considering the criteria based on assessing the model compliance and comparing the goodness of fit results with reference values, it is seen that results obtained were quite good. According to the results in Table-3, the test of leadership and organizational commitment dimensions with the structural equation model is appropriate.

\section{Path Analysis}

In the confirmatory factor analysis phase, by examining the reliability, validity and goodness of fit indices of the structures, it was determined that the test of the research model with the structural equation modeling was appropriate. In this section, path analysis, which is the next stage of CFA within the scope of SEM, was applied. Multiple regression analyses were performed with path analysis and hypotheses were tested simultaneously. In order to determine the compliance of the model tested by path analysis, some indices are used as in the CFA stage. These indices were examined and found to be of quite good value. The values obtained indicate that the proposed model is successful. Goodness of fit values of the model are shown in Table-4.

Table 4: Path Analysis- Goodness of Fit Indices

\begin{tabular}{lllll}
\hline$\chi^{2} / \mathbf{d f}$ & CFI & TLI & IFI & RMSEA \\
\hline 1.950 & 0.857 & 0.845 & 0.859 & 0.07 \\
\hline
\end{tabular}

The hypotheses established within the scope of the research model were tested by path analysis. The results of six hypotheses examining the effects of transformational and laissez-faire leaderships on three dimensions of organizational commitment are shown in Table-5.

\section{Table 5: The Effects of Transformational and Laissez-Faire Leaderships on Organizational Commitment Types}

\begin{tabular}{|l|l|l|l|l|l|l|l|}
\hline Hypothesis & $\begin{array}{l}\text { Organizational } \\
\text { Commitment Types }\end{array}$ & & Leadership Types & Estimate & $\begin{array}{l}\text { Standard } \\
\text { error }\end{array}$ & $\begin{array}{l}\text { Critical } \\
\text { ratio }\end{array}$ & p value \\
\hline $\mathrm{H}_{1}:$ Supported & Affective Commitment & $<--$ & $\begin{array}{l}\text { Transformational } \\
\text { Leadership }\end{array}$ & .538 & .064 & 6.138 & $* * *$ \\
\hline $\mathrm{H}_{2}:$ Supported & Continuance Commitment & $<--$ & $\begin{array}{l}\text { Transformational } \\
\text { Leadership }\end{array}$ & .315 & .058 & 3.601 & $* * *$ \\
\hline $\mathrm{H}_{3}:$ Supported & Normative Commitment & $<--$ & $\begin{array}{l}\text { Transformational } \\
\text { Leadership }\end{array}$ & .504 & .068 & 5.690 & $* * *$ \\
\hline $\mathrm{H}_{4}:$ Rejected & Affective Commitment & $<--$ & $\begin{array}{l}\text { Laissez-faire } \\
\text { Leadership }\end{array}$ & -.003 & .092 & -.041 & .967 \\
\hline $\mathrm{H}_{5}:$ Supported & Continuance Commitment & $<--$ & $\begin{array}{l}\text { Laissez-faire } \\
\text { leadership }\end{array}$ & .249 & .103 & 2.568 & .010 \\
\hline $\mathrm{H}_{6}:$ Supported & Normative Commitment & $<--$ & $\begin{array}{l}\text { Laissez-faire } \\
\text { leadership }\end{array}$ & .177 & .105 & 2.058 & .040 \\
\hline
\end{tabular}

According to the multiple regression analysis results obtained by the structural equation modeling in Table5 , five of the six hypotheses established have been supported and only one (H4) has been rejected. Accordingly, transformational leadership positively affects all 3 types of organizational commitment. Results of the research model are shown in Figure 1.

In Figure-1, the dashed lines refer to rejected, the straight lines refer to supported hypotheses, as a result of path analysis applied within the scope of structural equation modeling. Accordingly, the H4 hypothesis was rejected and all other hypotheses were supported, at $\mathrm{p}<0.05$ significance level. When standardized regression coefficients are examined, it is seen that the effect of transformational leadership on affective commitment $(\mathrm{H} 1: \beta=0.54, \mathrm{p}<0.001)$ is the hypothesis that has the highest effect in the model. The findings of the research indicate that transformational leadership positively affects all types of organizational commitment at a very high level of significance $(\mathrm{p}<0.001)$. Laissez-faire leadership, on the other hand, 
positively affects normative and continuance commitments, but it has no significant effect on affective commitment.

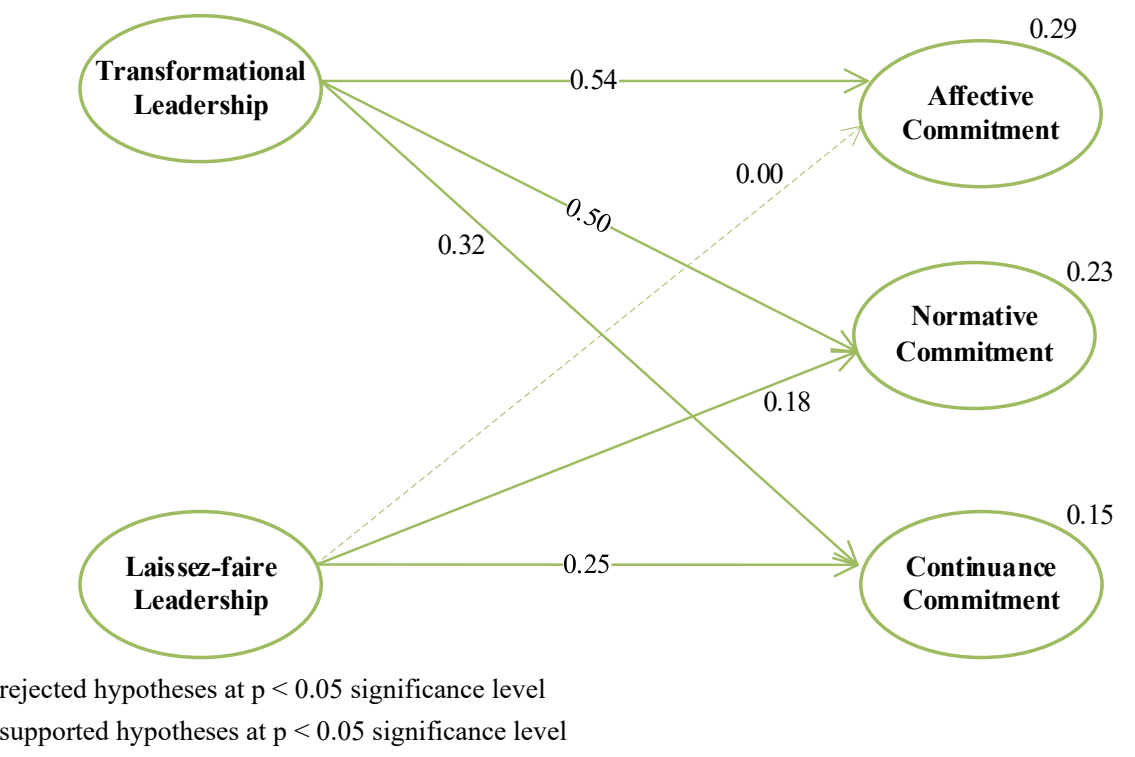

\section{Figure 1: Path Analysis for the Effects of Transformational and Laissez-Faire Leaderships on Organizational Commitment}

\section{CONCLUSION}

In this study, it is examined that how the transformational and laissez-faire leadership perceptions of employees effect their commitment to their institutions. The study was carried out with employees working in temporary staff at an important public hospital in Istanbul. Research results show that five of the six hypotheses proposed were supported. According to these results, the strongest effect determined $(0.54)$ is the effect of transformational leadership on affective commitment. In other words, transformational leadership behavior increases affective commitment to the institution. Because, transformational leadership encourages, excites and supports employees, and enables them to feel good and to improve themselves. Therefore, this is quite an expected result for an employee to have affective commitment to an organization where the leader exhibits such behavior.

Transformational leadership has a meaningful and positive effect $(0.50)$ on normative commitment, too. According to this result, transformational leaders who consider the individual needs of the employees, support their personal development and give meaning to their work by instilling vision, ensure employees having a normative commitment to the organization. Employees with normative commitment think it will not be morally correct to leave an organization that provides these opportunities and supports them in all matters.

Transformational leadership also has a positive impact (0.32) on continuance commitment. This shows that employees prefer to continue their membership in the organization, considering that in another organization, they will not find the appropriate working conditions and supports provided to them thanks to transformational leaders. In other words, they continue their membership because they think that their benefit requires as such and they will not find another organization that offer better opportunities if they leave the organization.

On the other hand, it is seen that laissez-faire leadership positively affects $(0.25)$ the continuance commitment. Employees are likely to feel important and empowered by a laissez-faire leader who gives employees a complete freedom to make decisions about their work and to complete their work and who encourages them to take initiative and take responsibility. Since they think that they cannot find this feeling in another organization, the employees show continuance commitment to the organization they work for and do not think of leaving as long as their interests continue. 
Laissez-faire leadership also positively affects normative commitment (0.18). Accordingly, by providing employees with opportunities such as decision-making, taking initiative and taking responsibility, laissezfaire leadership makes them feel stronger and more important. Therefore, employees do not find it morally correct to leave a leader, and therefore to leave the organization.

Exclusively, in the study, there was no meaningful relationship between laissez-faire leadership and affective commitment. This is mainly because laissez-faire leaders often have a passive nature that avoids decision-making and taking responsibility, which cannot be reached even when needed. Therefore, employees cannot be expected to show affective commitment to a leader and the organization of that leader, who does not support when they need it, who does not take risks and avoids taking responsibility.

As a result, transformational leadership behaviors increase normative and continuance commitments as well as the affective commitment, which is most desired by organizations. Affective commitment means adopting the mission and objectives of the organization, identification with the organization, supporting organizational activities and making extra efforts for the interests of the organization.

Therefore, health care businesses that want to make maximum use of the physical and intellectual abilities of temporary staff health care workers should prefer and rigorously implement the transformational leadership, which constantly encourages, excites and supports employees and enables them to feel better and improve themselves. 


\section{REFERENCES}

Acar, A. Z. (2012). Organizational Culture, Leadership Styles and Organizational Commitment in Turkish Logistics Industry, Procedia - Social and Behavioral Sciences. 58, 217-226.

Acar, M.F., Zaim, S., Isik, M. and Calisir, F. (2017). Relationships among ERP, supply chain orientation and operational performance: An analysis of structural equation modeling, Benchmarking: An International Journal, 24(5), 1291-1308.

Allen, N.J. and Meyer, J.P. (1990), The measurement and antecedents of affective, continuance and normative commitment to the organization. Journal of Occupational Psychology, 63, 1-18.

Avolio,B.J.,Bass,B.M.,\&Jung,D.I.(1999).Re-examining the components of transformational and transactional leadership using the Multifactor Leadership Questionnaire.Journal of Occupational and Organizational Psychology, 72(4), 441-462.

Avolio, B.J., Zhu, W., Koh, W. and Bhatia, P. (2004), Transformational leadership and organizational commitment: mediating role of psychological empowerment and moderating role of structural distance. J. Organiz. Behav., 25, 951-968.

Aydın, A., Sarıer, Y., and Uysal, S. (2013). The effect of school principals' leadership styles on teachers' organizational commitment and job satisfaction. Educational Sciences: Theory \& Practice, 13(2), 806811.

Aysel, L. (2006). Liderlik ve Duygusal Zekâ, Yüksek Lisans Tezi, Kocaeli Üniversitesi Sosyal Bilimler Enstitüsü İşletme Anabilim Dalı.

Bagozzi, R. P., Yi, Y. (1988). On the Evaluation of Structural Equation Models, Journal of the Academy of Marketing Science, 16(1), 74-84.

Bass, B. M., (1985). Leadership: Good, Better, Best, Organizational Dynamics, 12, $26-40$.

Bass, B. M., (1990). From Transactional to Transformational Leadership: Learning The Share Vision, Organizational Dynamics, 18(3), 19-31.

Bass, B. M., (1997). Personal Selling and Transactional/Transformational Leadership", Journal of Personal Selling \& Sales Management, 17(3), 19-28.

Bass. B. M. (1998). Transformational Leadership: Industrial, Military, and Educational Impact. Mahwah, NJ: Lawrence Erlbaum Associates.

Bass, B. M., (1999). Two Decades of Research and Development in Transformational Leadership, European Journal of Work and Organizational Psychology, 8(1), 9-32.

Batmunkh, M., (2011). Liderlik Tarzları ile Örgütsel Bağl1lık ve Örgütsel Sessizlik arasındaki İlişki ve Bir Araştırma, Yüksek Lisans Tezi, Marmara Üniversitesi, İstanbul, 2011.

Becker, H., (1960). Notes on the Concept of Commitment, American Journal of Sociology, 66(1), pp. 3242.

Bohn, J.G., Grafton, W.I., (2002). The Relationship of Perceived Leadership Behaviors to Organizational Efficacy", The Joumal of Leadership and Organization Studies, 9(1), 65-79.

Bollen, Kenneth A. (1989). Structural Equations with Latent Variables, USA, A Wiley-Interscience Publication, John Wiley \& Sons, Inc.

Brewis, Linstead, S., 2004: Gender and Management, içinde Linstead, S., Fulop, L., Lilley, S. (Eds.), Management and Organisation: A Critical Text,Chapter 2, MacMillan, Palgrave.

Bull Schaefer,R.A.,Green,S.G.,Saxena,M.,Weiss,H.M.\&MacDermid Wadsworth S.M., (2013).Crossover of Organizational Commitment, Human Performance, 26:4,261-274.

Campbell, D. T., Fiske D. W. (1959). Convergent and Discriminant Validation by the MultitraitMultimethod Matrix, Psychological Bulletin, 56(2), 81-105. 
Cook, J., Wall, T., (1980). New Work Attitude Measures of Trust, Organizational Commitment and Personal Need Nonfulfilment, Journal of Occupational Psychology, 53, 39-52.

Curtis, M. B., \& Taylor, E. Z. (2018). Developmental mentoring, affective organizational commitment, and knowledge sharing in public accounting firms. Journal of Knowledge Management, 22(1), 142-161.

Çakinberk, A., Demirel, E. T. (2010). Örgütsel Bağlılığın Belirleyicisi Olarak Liderlik: Sağlık Çalışanları Örneği, Selçuk Üniversitesi Sosyal Bilimler Enstitüsü Dergisi, 24, 103-119.

Çöl, G., (2004). Örgütsel Bağl1lık Kavramı ve Benzer Kavramlarla İlişkisi, İş Güç Endüstri İlişkileri ve İnsan Kaynakları Dergisi, 6(2),

$\mathrm{http}: / /$ www.isgucdergi.org/?p=article\&id=233\&cilt=6\&sayi=2\&yil=2004.

Deitzer, B., Shilliff, K. \& Jucius, M., (1979). Contemporary Management Concepts, Grid Publishing, Inc.

Dubin, R. Champoux, J.E., (1975). Central Life Interests and Organizational Commitment of Blue-Collar and Clerical Workers,Administrative Science Quarterly,20(3),411-421.

Durna, U.; Eren, V., (2005). Üç Bağl1lık Unsuru Ekseninde Örgütsel Bağl1lık, Doğuş Üniversitesi Dergisi, 6(2), 210-219.

Eren, E., (2012). Örgütsel Davranış ve Yönetim Psikolojisi, 13. bs., Beta Basım Yayım Dağıtım A.Ş., İstanbul.

Erdem, R., (2007). Örgüt Kültürü Tipleri ile Örgütsel Bağlllık Arasındaki İlişki: Elazığ İl Merkezindeki Hastaneler Üzerinde Bir Çalışma, Eskişehir Osmangazi Üniversitesi İIBF Dergisi, 2(2), 63-79.

Eryeşil K., İraz, R. (2017). Liderlik Tarzları ile Örgütsel Bağlılık Arasındaki İlişkinin İncelenmesine Yönelik Bir Alan Araştırması. Sosyal Bilimler Meslek Yüksekokulu Dergisi, 20(2): 129-139.

Gaskin, J. \& Lim, J. (2016), Master Validity Tool, AMOS Plugin. Gaskination's StatWiki.

Grusky, O., (1966). “Career Mobility and Organizational Commitment”, Administrative Science Quarterly, 10(4), 488-503.

Hair Jr., J. F.; Black, W. C.; Babin, B.J.; Anderson, R.E. (2010). Multivariate Data Analysis, 7th ed., New Jersey, Upper Saddle River, Pearson Prentice Hall.

Hair Jr., J. F.; Black, W. C.; Babin, B.J.; Anderson, R.E. (2014a). Multivariate Data Analysis, Pearson New International Edition, Great Britain, Edinburgh, Pearson Education Limited.

Hair Jr., J. F.; Hult, G.T.; Ringle, C.M.; Saistedt, M. (2014b). A Primer on Partial Least Squares Structural Equation Modeling (PLS-SEM), USA, Sage Publications.

Hartmann, L.C. and Bambacas, M. (2000), Organizational Commitment: A Multi Method Scale Analysis and Test of Effects, The International Journal of Organizational Analysis, 8(1), 89-108.

Harvey, D.F., Brown, D.R., 1988: An Experiential Approach to Organization Development, 3. bs., USA, Prentice-Hall International.

Hrebiniak, L.G., Alutto, J.A., (1972). Personal and Role-Related Factors in the Development of Organizational Commitment, Administrative Science Quarterly, 17(4), 555-573.

Judge, T.A., \& Piccolo, R.F. (2004).Transformational and Transactional Leadership:A Meta-Analytic Test of Their Relative Validity.Jour of Applied Psychology,89(5),755-768.

Kanter, R.M.,(1968).Commitment and Social Organization: A Study of Commitment Mechanisms in Utopian Communities, American Sociological Review,33(4),499-517.

Kidron, A., (1978). Work Values and Organizational Commitment, Academy of Management Journal, 21(2), 239-247.

Kim, H., (2014). Transformational Leadership, Organizational Clan Culture, Organizational Affective Commitment, and Organizational Citizenship Behavior: A Case of South Korea's Public Sector, Public Organization Review, 14, 397-417. 
Kitchin,D., 2010: An Introduction to Organisational Behaviour for Managers and Engineers: A Group and Multicultural Approach, USA, Butterworth-Heinemann, Elsevier.

Kline, R. B. (2011). Principles and Practice of Structural Equation Modeling, 3rd. ed., USA, New York: The Guilford Press.

Koçel, T., 2005: İşletme Yöneticiliği.10.ed. İstanbul: Arıkan Basım Yayım Dağıtım Ltd. Şti.

Marsh, H. W., \& Hocevar, D. (1985). Application of Confirmatory Factor Analysis to the Study of SelfConcept: First- and Higher Order Factor Models and Their Invariance Across Groups, Psychological Bulletin, 97(3), 562-582.

Meyer, J. P., Allen, N. J., (1991). A Three-Component Conceptualization of Organizational Commitment, Human Resources Management Review, 1(1), 61-68.

Meyers, L. S. \& Gamst, G., \& Guarino, A. J. (2006). Applied Multivariate Research: Design and Interpretation. USA, Thousand Oaks: Sage Publications.

Mowday, R.T., Steers, R.M., Porter, L.W. (1979). The Measurement of Organizational Commitment, Journal of Vocational Behavior, 24(2), 224-247.

Özoğlu, B. \& Bülbül, H. (2013). Güdülenmiş Tüketici Yenilikçiliği ve Algılanan Risk Ölçeklerinin Geçerlilik ve Güvenilirlik Çalışması, Uluslararası Alanya İşletme Fakültesi Dergisi, 5(3), 131-139.

Peterson, S.J., Walumbwa, F.O., Byron, K., Myrowitz, J., 2009. CEO Positive Psychological Traits, Transformational Leadership and Firm Performance in High-Technology, Start-Up And Established Firms, Journal of Management, 35(2), 348-368.

Porter, L.W., Steers, R.M., Mowday, R.T., Boulian, P.V., (1974). Organizational Commitment, Job Satisfaction, and Turnover among Psychiatric Technicians, Journal of Applied Psychology, 59(5), 603609.

Porter, L.W., Crampon, W.J., Smith, F.J., (1976). Organizational Commitment and Managerial Turnover: A Longitudinal Study, Organizational Behavior \& Human Performance, 15(1), 87-98.

Posey, C., Roberts, T. L. and Lowry, P. B. (2015). The Impact of Organizational Commitment on Insiders' Motivation to Protect Organizational Information Assets, Journal of Management Information Systems, 32(4), 179-214.

Ritzer, G., Trice, H. M., (1969). An Empirical Study of Howard Becker's Side-Bet Theory. Social Forces, 47(4), 475-479.

Robbins, S.P., Coulter, M., 2012: Management, 11. ed. USA, New Jersey: Pearson Education Inc., Prentice Hall.

Rossel, R.D., (1971). Required Labor Commitment, Organizational Adoption, and Leadership Orientation, Administrative Science Quarterly, 16(3), 316-320.

Sadeghi, A., Pihie, Z.A.L. (2012). Transformational Leadership and Its Predictive Effects on Leadership Effectiveness. International Journal of Business \& Social Science, 3, 186-197.

Salepçioğlu, M.A., Yeğin, A. (2018). Liderlik Tarzlarının Çalışanların Örgütsel Bağlılıklarına Etkisi ve Bir Uygulama, Cumhuriyet Üniversitesi İktisadi ve İdari Bilimler Dergisi, 19(1), 60-77.

Schermelleh-Engel, K., Moosbrugger H. \& Müller H. (2003). Evaluating the Fit of Structural Equation Models: Tests of Significance and Descriptive Goodness-of-Fit Measures, Methods of Psychological Research Online, 8(2), 23-74.

Scholl, R. W, (1981). Differentiating Commitment from Expectancy as a Motivating Force, Academy of Management Review, 6(4), 589-599.

Thornton, R., (1970). Organizational Involvement and Commitment to Organization and Profession, Administrative Science Quarterly, 15(4), 417-426.

Tseng, W.-T., Dörnyei, Z., Schmitt, N. (2006). A New Approach to Assessing Strategic Learning: The Case of Self-Regulation in Vocabulary Acquisition, Applied Linguistics, 27(1), 78-102. 
Uyguç, N., Çımrın, D. (2004). DEÜ Araştırma ve Uygulama Hastanesi Merkez Laboratuvarı Çalışanlarının Örgüte Bağlılıklarını ve İşten Ayrılma Niyetlerini Etkileyen Faktörler, Dokuz Eylül Üniversitesi İktisadi ve İdari Bilimler Fakültesi Dergisi, 19(1), 91-99.

Ülgen,H.\&Mirze, K.,(2007). İşletmelerde Stratejik Yönetim,4.bs.,İstanbul,Arıkan yayınları.

Wang, Y.S., Huang, T.C., 2009. The Relationship of Transformational Leadership with Group Cohesiveness and Emotional Intelligence, Social Behaviour and Personality, 37(3), 379-392.

Warrick, D.D., (2011). The Urgent Need for Skilled Transformational Leaders: Integrating Transformational Leadership and Organization Development, Journal of Leadership, Accountability and Ethics, 8(5), 11-26.

Wiener, Y., (1982). Commitment in Organizations: A Normative View. Academy of Management Review, 7(3), 418-428.

Wiener, Y., \& Vardi, Y. (1980). Relationships between job, organization, and career commitments and work outcomes: An integrative approach. Organizational Behavior \& Human Performance, 26(1), 81-96.

Yousef, D.A. (2017). Organizational Commitment, Job Satisfaction and Attitudes toward Organizational Change: A Study in the Local Government, International Journal of Public Administration, 40:1, 77-88.

Yukl, G., (1999). An Evaluative Essay on Current Conceptions of Effective Leadership, European Journal of Work and Organizational Psychology, 8(1), 33-48.

Yücel, I., McMillan, A. and Richard, O. C. (2014). Does CEO Transformational Leadership Influence Top Executive Normative Commitment?', Journal of Business Research, 67, 1170-1177.

Yüceler, A. (2009). Örgütsel Bağlılık ve Örgüt İklimi İlişkisi: Teorik ve Uygulamalı Bir Çalışma, Selçuk Üniversitesi Sosyal Bilimler Enstitüsü Dergisi, 22, 445-458. 